\title{
Assisted Christian Schools Governance, Practices, Boards Commitments and Performance Measures in Sri Lanka
}

\author{
Sr. Mary Selinta Fernando ${ }^{1}$, Kennedy D Gunawardana ${ }^{2}$, Y K Weerakoon Banda ${ }^{3}$ \\ ${ }^{1}$ Faculty of Graduate studies, University of Sri Jayewardenepura, Sri Lanka \\ ${ }^{2}$ Department of Accounting, Faculty of Management Studies and Commerce, University of Sri Jayewardenepura, \\ Sri Lanka \\ ${ }^{3}$ Department of Finance, Faculty of Management Studies and Commerce, University of Sri Jayewardenepura, Sri \\ Lanka \\ Correspondence: Sr. Mary Selinta Fernando, Faculty of Graduate studies, University of Sri Jayewardenepura, Sri \\ Lanka.
}

Received: May 14, 2018

doi:10.5539/ibr.v11n8p97
Accepted: June 29, $2018 \quad$ Online Published: July 19, 2018

URL: https://doi.org/10.5539/ibr.v11n8p97

\begin{abstract}
Education has been playing the most important pivoting role in the development of human civilization in the present. Hence, education is inseparable and it is imperative to cater to the present needs of the society and prepare the society for a better future. One of the most valuable gifts that the Catholic Church has contributed is the holistic approach in the education, as we need to compete for Knowledge and wisdom; true education is not only training the mind but also the heart leading to wisdom. However the overall performance of the holistic education system faced wide spread controversy and continuing concern about how schools are being managed and controlled has led to many studies on school performance. The purpose of the study is provided evidence from single or a few perspectives such as selected indicators and school governance principals. In addition, there are many inconsistencies in the finding across the world that shows no signal school governance model is appropriate for all schools, countries and economic environments. The study has considered the three different school governance practicess of board clear funtion, sustainable policy, and board charter in capturing the effect of board governance on school performance. In addition, to elucidate school performance is dealing with board governance; the study used four perspective of balance score card as a determinant of school performance. The estimation results suggested that the board clear function, sustainable policy and board charter had significant positive driving forces on school performance.
\end{abstract}

Keywords: education, catholic church, school performance, governance, boards commitments

\section{Introduction}

\subsection{Introduce the Problem}

Education has been playing the most important pivoting role in the development of human civilization in the present. Hence, education is inseparable and it is imperative to cater to the present needs of the society and prepare the society for a better future. It is inevitable that such issues as "knowledge explosion", development of knowledge, new technology and insulating cultural values and norms of the society are crucial to fulfil the true sense of development. Education is a continuous process whether one likes it or not. Each person in society is an integral part in this process. Education can either be a formal or/and an informal process where knowledge and skills are developed when the learner is exposed to a new environment. In the process of educating the society, invariably education institutions, mainly the primary schools play the pioneering role to begin with, where the important foundation for future development of productivity of a nation completely relies. With the focus on icon appraisal, it identifies an effective method of assessing the level of the standard of the school in contributing its share to make a better tomorrow. As a country develops, it is expected to enhance the overall quality of living. As almost everyone in any society works in some kind of organization, they are ultimately confronted on a daily basis with the actions of those in other organizations take. It may be a business firm or school. The main concept of this study is directed towards the operationalization of the school performance concept in order for it to be measured. A major theme in educational research has been the effect of schooling on school performance. 
Differences in student achievements and performance between schools were found to be much smaller than within-school differences. Research has revealed that the most influential factors at school level were student and teacher characteristics such as educational beckground, teacher's competence et cetra. Furthermore, the research reveals that factors such as the curriculum of the school, its facilities and teachers' salaries et cetera do not play a substantial impact in student achievement. Furthermore, student achievements can be boosted by a positive school atmosphere, a committed and involved educational leadership, involvement of school management and parents and monitoring students' progress.

\subsection{Explore Importance of the Problem}

The beginning of the education in Sri Lanka runs many centuries back and it first started with transferring knowledge orally from one generation to another. Firstly, the religious knowledge and philosophies of Buddhism were encapsulated into small verses and delivered by trained pupils. Afterwards, knowledge was written in Ola Leaf Manuscripts and kept in libraries in temples. In those days, learning was confined to religion, philosophy, languages, grammar, literature, et cetera. All education centers (pirivenas or monastic colleges) targeted the production of the clergy and taught a very small number of other students. Understanding of Hindu education was inadequate but there would have been schools based on Hindu temples and they might have been modernized during the Portuguese and the Dutch eras. With the arrival of the Arabs, Muslim education started in the late fifteenth Century and centralized at mosques where the Quran was recited and practiced. After the Portuguese captured the Sinhala Kingdom, education system was reformed by the missionaries who established schools to foster their religion, Roman Catholicism. Parish schools were organized for reading, writing and scriptures and were taught in the mother language. The elementary education was provided to all in the parish while the secondary education was delivered only to the children of the Portuguese civil and military officers or the local chieftains. Other than the scriptures, secondary education was replenished with humanities and rhetoric.

During the Dutch governance, the education system expanded and a number of schools were set up catering to a larger number of children. They took a fair degree of control of such schools under the government from the clergy due to the suspicion that Catholics would support the Portuguese. They established Scholarship Commissions to supervise the schools. It was in 1869 that the British Government in Sri Lanka permitted religious denominations to open and run schools for their children with state aid. The Catholic Church went ahead establishing schools in parishes. The British established Mass Education System in Sri Lanka in the Nineteenth century. They first started schools jointly with the clergy assisted by the government. Later on the government realized the need of the education for the natives as well as the trade and the plantation sectors and designed supportive education. Hence, the dual education system was born. One type of schools operated in the English medium and was fee levying. The other type was the state schools which taught in the mother tongue of children of native common people. With the increase of schools, the government established the Department of Public Instruction to maintain the standard of education and the more they realized the importance of education for natives to mitigate crimes.

By the Twentieth century, Buddhist and Hindu leaders formed their own schools; Buddhist started the Theosophical Society to establish schools with Buddhist culture and Hindu leaders started their own schools with Hindu environment for Hindu children. Subsequently, a number of assisted schools rapidly increased. In the semi independence period, Dr. C. W. W. Kannangara gave rise to a treasured initiation for the prevailing education system and he was able to establish many enactments of education laws, expansion of education and free education from kindergarten to university education on behalf of the native Sri Lankans. With the guidance of Dr. Kannangara's education reforms in the post independent era education was nourished and further expansion of the education system was sustained. 1960-1961 periods were another landmark year in the Sri Lankan education system. The National System of Education was established and under this system except for a few schools, the majority were taken over and maintained under the government. Some degree of rationalization was made possible. The Curriculum Development Center (CDC) established in the 1960s was responsible for School Curriculum Development. The National Institute of Education (NIE) was founded in 1985 with the objective of professional development of teachers, principals and educational administrators. The National Education Commission (NEC) was established with the faith of formulating a national policy on education by an act of parliament. Sri Lankan education system has undergone many reforms periodically to cater to the national and international demands and standards. The reforms carried out in 1947, 1960-61, 1972, 1987, 1992, and 2006 are amongst the most important landmarks in the History of Sri Lankan Education.

Theoretically, the current study will examine the factors that contribute to school performance from the school governance and board ethical commitment perspectives. Based on the research framework of the study, the interdependent variable, school governance will be represented by eight indicators or variables namely, Board 
responsibility, Board composition, Board interdependence, Board commitment, Financial reporting integrity, Balance scorecard, School disclose and shareholders' relation. The primary objective is to examine the interaction effect between school governance and board ethical commitment on the performance of the school and the secondary objectives are related to develop sub-indices for the principles of school governance using multiple indicators for each principle, to develop a measure for board ethical commitment and to examine the extent of school rules and regulations with performance measurement will be examined.

\subsection{Describe Relevant Scholarship}

Board of governance embodies the way a company is directed and controlled (Cadbury Committee, 1992). It provides a mechanism to align the interests of various stakeholders via policies and guidelines for the company to pursue its objectives and the context of the economic regulatory and social environments. Board governance has become an important subject since the collapse of large organizations and fraud by global market players. There are many international bodies like International Board Governance Network (ICGN) and Organization for Economic Co-operation and Development (OECD) that have developed board governance recommendations, the ICGN for example, aims to promote effective standards of board governance to promote efficient markets. Its members comprise global investors from more than 50 countries with assets management in excess of USD26 trillion. On the other hand, OECD works with the governments from various countries to seek solutions on economic, social and environmental problems, while at the same time promoting policies to improve the economic and social well-being of the people around the world. In the US it has significantly influenced the way introduction of the Sarbanes Oxley Act (2002) as to how corporations conduct their business.

There are a number of ways how different models of board governance can be classified. Realizing that no one model of board governance can fit all companies (Skare and Hasic, 2016) as different countries have different sets of laws and regulations, a different approach on board governance is required to align with the operation and management of the companies. For example, it is common for US companies to have a widespread shareholding structure as compared to European companies where concentrated and family-based shareholding is more familiar. Thus, external orientations based on board governance such as take-over rules, shareholders' rights and regulating the work of CEO are more effective in controlling the US companies meanwhile, internal orientations based on board governance like emphasizing on board independence and separation of power between the CEO and the Chairman of the company are more successful in regulating European companies.

Razaee (2008) suggests board governance throughout the world can be divided into close, open and hybrid. The close model is characterized by the three models concentration of ownership and debt capital, less dependence on the capital market, more direct control and oversight by a few major investors such as banks, insurance companies and individual, focus on internal information flow and less information asymmetries between manager and shareholders. On the other hand, the open model is well known as a market based or outsider model. This model is characterized by widespread, diffused and concentrated ownership, high reliance on the capital market to finance business, separation of managerial and oversight function less regulated governance and board activities, focus on extremely information flow and existence of information asymmetries. The last model, the hybrid model is a combination of both the close and open models The close model suggested by Rezaee (2008) is identical with the European model that is predominant in European countries like Germany, while the open model is close to the Anglo-Saxon model that is widely practiced in the US. The open and close models are also known as one-tier and two-tier system of governance respectively by some scholars (Skare and Hasic, 2016).

Another way to classify governance is based on its approaches to disclosure prescriptive, non-prescriptive and hybrid (Finance Committee on Board Governance, 2000). The prescriptive approach is where the standard of board governance has specific requirements and practices, in which the companies are required to disclose their compliance. The companies act and the listing requirements of the stock exchange adopt this approach. The second is the non-prescriptive approach which simply requires board governance practices in a company to be disclosed without any specific or rigid guidelines. The emphasis of this approach is the disclosure of the actual board governance practices. Appreciating that every company is unique, this approach requires the company itself to address their board governance needs that are possibly different from other companies. The last approach is the hybrid approach which considers that there is a need for principles that are broad and general. The companies can apply these guidelines flexibly to the varying circumstances of individual companies. This is known as the "comply and explain" approach. This means that the company has a choice whether to comply or not with the prescribed principles. However, if the company chooses not to comply, the company needs to disclose why it does not comply and the alternative practices or principles that are used to substitute for the prescribed principles. 


\subsection{State Hypotheses and Their Correspondence to Research Design}

Prior studies in board governance show that good board governance practices contribute to good performance of a school. For example, a survey by credit Lyonnais Asia (CLSA) in the emerging markets found that board governance significantly influences board performance. The survey also shows that board governance is positively related with higher return equity, better expenses management and control, more profits superior performance in the stock market and having higher than average return to shareholders. Likewise, another study conducted by Gomper, Ishii and Metrick (2003) also found similar results. Good practices of board governance will give superior return to the shareholders, low cost of capital and higher firm values, sales growth and profitability. There are seven (7) principles examined and tested against board performance in this study, namely board responsibility, board composition, board independence, board commitment, risk management, board disclosure and stakeholders correlation. One of the important mechanism of board governance is board responsibility. Jensen (1993) described the board as the apex of the internal control system of the school. This consists of requirements for the board to have a clear function and responsibilities, commitment to sustainability, good access to information and to establish a board charter. The board will be able to perform its duty effectively when its responsibility is clearly set out (Bebchuk and Weisbach, 2010). For example, Bohm, Bollen and Hassink (2016) found a relation between the scopes of responsibilities set forth in audit committee charters and the frequency of audit committee meetings. Among others, the principles are responsible for monitoring managerial and staff performance, ratifying decisions, providing incentives and aiding strategic planning activities. These responsibilities can be viewed from two different perspectives, first with the board as an advisor and second, with the board as a monitor of the management team (Armstrong, Guay and Weber, 2010).

Agency theory suggests that boards are expected to ensure that the stakeholders' interests are met (Fama and Jensen, 1983) when fulfilling its fiduciary duty to all key stakeholders whereas in this study the management including the principle is expected to satisfy the needs of the customer who are the parents (Blair, 2012). Geletkanycz and Boyd (2011) suggests that when the performance of a company deteriorates, the board will take necessary actions such as revising firm direction, finding valuable resources (Boeker and Goodstein, 1991) and supporting the management team (Carpenter and West phal, 2001) to turn the company around, which will also be the same situation in a school setting. As another example, Tuggle et al. (2010) found that negative performance by a company will increase board attention to monitor and execute disciplinary actions on management whereas in a school, negative performance will cause the school board to closely monitor the teaching staff. (Bhagat and Bolten, 2008). This also forms part of the principal's accountability not only to the staff but also to all other stakeholders in general (Kaey and Loughrey, 2015). As an example, in the banking sector, Jian and Thomson (2008) found that a bank's poor performance is consistent with lack of accountability, poor board governance and board dysfunction, which is associated with fraudulent trading activities. However at the same time, the board does not take tax risks such as underpaid tax and non-compliance with tax regulations that could create a negative impact on its performance, financial statements and reputations. Based on these arguments, the first hypotheses is:

- Hla: There is a relationship between the existence of a board's clear function and responsibilities based on assisted school performance.

Promoting sustainability that comprises of environmental, social and governance elements in addition to economic aspects of a business will enhance the reputation of the company as a good citizen in society, same as a school where these elements would uplift its reputation (Orsato, 2006). Furthermore, Perrini and Tencati (2006) suggests that a company creates value when it adopts sustainability-oriented managerial approach. When a school adopts sustainability-oriented managerial approach that too enhances the face value of the institute as an organization. Lopez et al. (2007), for example found the differences in performance between listed and non-listed companies in the Dow Jones sustainability Index. They suggest that firms that inboard sustainability as part of their strategy will have competitive advantage over their competitors who do not adopt this approach (Adams and Zutshi, 2004). A sustainability strategy, which includes consideration of quality, environment, branding, reputation, customer loyalty and human development, will move a company to have better board management as well as in an assisted school setting, where the board will increase its efficiency in board governance, (Orlitzky, Schmidt and Rynes, 2003), good systems, internal control, decision making and cost savings (Adams, 2002) and thus, have a superior performance. Empirical research also suggests that environmental and social performance and its disclosure may affect the schools access to finance (Cheng, Ioannou and Serafeim 2014) and affect significantly and positively the organizational performance (Nobanee and Ellili, 2016).

- H2a: There is a relationship between the adoption of a sustainability policy promoted by the board and 


\section{assisted school performance}

The effectiveness of principles in the performance of their duty is limited by the availability of information and costs associated with acquiring such information (Adams and Ferreira, 2007; Reheja, 2005). The board requires firm specific knowledge and good information to help them perform their role as a principal both as a monitor and advisor. (Armstrong et al., 2010; Bebchuck and Weisbach, 2010). For example, Jensen (1993) admits that even highly talented and experienced directors are unable to perform their roles effectively if they receive limited information, whereas in schools the lack of information received from both the staff and the parents' results of poor performance of the job role of a principal. Because of that, a good principal will be able to overcome a limited information environment by searching for alternative information sources from third parties and soft information from on-going networking relationship (Cassar, Ittner and Cavalluzzo, 2015). Other than that, the board is in a better position to perform its monitoring role of observing the performance of the school due to the information advantages that they possess as compared to outside monitors (Jensen and Meckling, 1976; Fama and Jensen, 1983; Inderst and Mueller, 2010; Ravina and Sapienza, 2010; Ashwin, Krishnan and George, 2016). As such, a conducive information environment is important when resolving agency conflict between various groups inside and outside the school (Armstrong et al., 2010).

For example, limitation on the information system in generation facts and figures relevant to monitor managerial behavior will impair the effects of schools' governance. Principals need such information to help them understand factors that affect the bottom line figures of financial statement, hence, it aids them in the evaluation process (Bushman et al., 2004). When the board functions as an advisor to the institute, they also need rich information to make accurate decisions that will reduce the transaction cost of dealing with uncertainties in the environment (Hillman and Dalziel, 2003) and hence, prevents mistakes that will cost money to the school. Good access to information is critical for the board to make a short-term and long-term view of the school as an organization (Nicholson and Kiel, 2007), achieve successful innovation and it enhances the decision-making process (Donaldson and Davis, 1994). For instance, a study conducted by Baysinger and Hoskisson (1990) has found that the superior amount of quality of information possessed by internal directors is related to high quality investment to research and development ( $R$ and $\mathrm{D})$. Hence these arguments lead to the hypothesis below taking cognizance of a school, consistent with the argument forwarded in Signaling Theory.

- H3a: There is a relationship between the existence of a board charter and assisted school performance.

\section{Method}

A variable is an observable item which can assume different values (Smith, 2015; Sekaran \& Bougie, 2013). These values can be measured directly or indirectly, through the use of proxy or substituted variables. There are four types of variables in this study, namely dependent variables, independent or explanatory variables, moderating variables and control variables. Dependent variables are variables that are of primary interest to the researcher (Sekaran \& Bougie, 2013) and their variability is explained or influenced by independent variables. In this research, the dependent variable is the School performance. A comprehension of the Balance Score Card and the school performance for performance evaluation of children are essential for the school sector to predict their future expectations. The result of the present study will provide variable information to enhance to private sector catholic school performance and the research includes developing the testing of hypothesis in second stage. The study focuses on how the Privet sector school performance can be measured through Balance Score Card use. Further study forces objectives of to measure the private sector school performance, to introduce Balance Score Card as a measuring tool to measure the private sector school performance, to identify the driving and restraining forces in school performance. Finally researcher emphasise the challengers in implementing Balance score card to measure school performance in privet sector school in Sri Lanka. As a consequence, public organizations have been subjected to internal and external pressures in order to adopt practices and carry out actions, which will enable them on the one hand to manage their own impacts better and on the other hand to promote and encourage the adoption by other organizations of behaviours consistent with the preservation and protection. Measuring public sector performance is essential in today's context. This research is directed to measuring school performance through Balance score card. Although income statements, balance sheets, and other traditional accounting reports are useful to stockholders, potential investors, and analysts, such financial reports with their aggregated figures and focus on historical transactions are often of little use to internal managers. Further, traditional reports only indirectly measure the effectiveness of corporate strategy and can leave managers in the dark about whether a specific strategy has been implemented successfully. An independent variable is one that influences the dependent variable, either positively or negatively. A unit increase in the independent variable may cause an increase or decrease in the dependent variable (Sekaran and Bougie, 2013). The independent variables in this study are the board governance attributes of Board clear function, Sustainability policy Good access of information and Board charter. 


\subsection{Sampling Procedures}

Sampling is the process of selecting a sufficient number of elements from the population (Sekaran and Bougie, 2013). The population refers to an entire group of people, events or things of interest that the researcher wishes to investigate while an element refers to a single number of that population (Sekaran and Bougie, 2013). In the context of this research, the population refers to all the schools that are semi-government in Sri Lanka while an element might refer to any single school listed in the population.

For the purpose of this research, this study will include 20 semi-government schools registered under the Education Ministry of Sri Lanka. These particular groups of schools were selected based on the fact that they are highly valued by stakeholders, are secure and stable establishment with ease of access and due to the fact that they have shown major improvements within the past five years in academic and other areas.

The issue that may arise from selecting this type of a sample population of schools is that the research result may introduce bias towards the larger size of the schools. To resolve this issue, catholic/Christian semi-government schools were selected as a control variable so that the effect size will be observed when the statistical analysis is conducted later.

In addition, this sample group is used because it is impossible to study the entire population of schools in Sri Lanka due to the limitations of time and cost. In Sekaran and Bougie (2013) it mentions that studying a sample will lead to reliable results because fatigue is reduced, resulting in fewer errors in collecting and analyzing data.

Furthermore, the selected 20 schools for the data analysis of this research are considered sufficient due to several reasons. Firstly, it is because it represents more than 50 percent of the chosen category of schools which are Christian/ Roman Catholic semi-government schools. Therefore a sample of 20 schools represents approximately 67 percent to 63 percent of the total population of the chosen category. Secondly, the sample size is calculated based on the formula $\mathrm{N}>50+8 \mathrm{~m}$, as mentioned by Tabaachnick and Fidell (2013), where $\mathrm{m}$ is the number of independent variables and $\mathrm{N}$ is the total sample. Therefore since this study consists of 27 independent variables, the minimum size of the sample population should be $50+8(3)=74$ participants. Eventually, Stevens (2012) recommends 15 participants per predictor or independent variable for a reliable equation in social science research. Thus, based on Stevens (2012), the minimum sample of participants should be $15(3)=45$. In summary, the sample of 20 schools selected for this research is sufficient to contain 199 participants for this research.

\subsubsection{Measures and Covariates}

To evaluate board governance variables, the indices were developed from relevant reports. The board governance variables in this study will refer to the board governance guidelines as mentioned in the earlier sections. The information disclosed for all the indices of board governance will be measured using a 3-point Likert scale. "2" denotes beyond level of disclosure (more information), "1" indicates that there is a minimum disclosure while " 0 " score represents no disclosure (no information). Based on this, a formatted checklist was developed comprising numerous items, as the accumulated score for each item is used to measure sub-indices and ultimately the index.

A 3-point Likert scale is used rather than a 5-point or 7-point Likert scale because it is difficult to assess the governance practices by using the higher point Likert scales in which the differences between the points are marginal and difficult to gauge. For example, the possible 5-point Likert scale that can be developed for this study depiets very poor, poor, average, good and very good. It is very hard for the researcher to differentiate and measure between very poor and poor governance practices and also to indicate between good and very good governance practices. As far as this study is concerned, it is very hard to find a (or possibly none) board governance research that evaluates board governance practices using a 5-point Likert scale as mentioned above. In addition, knowing that there are many items to be scrutinized for each school as an organization, use of a 5-point Likert scale is tedious, time consuming and not feasible to be adopted.

These scales and measures were chosen due to their simplicity and ease of use (Neuman, 2006) and could be used to employ parametric significance test. The data items are also powerful enough to permit the use of regression analysis and other statistical analysis to examine the relationship between independent, moderating and dependent variables.

If a categorical measurement is used, the analysis will be restricted to a mainly non-parametric test. To avoid subjectivity and bias, all items will be considered of equal importance.

The initial instrument was validated by several experts comprising of academics with varying experiences in board governance to enhance its construct validity. After getting the response and the feedback, the final version of the instrument was used for the purpose of this study. A pilot study was then conducted to assess the instrument's feasibility. This was done by using the instrument to evaluate the board governance practices as 
disclosed in the annual reports produced by the schools. Then, this instrument was further refined to ensure that no items had overlapped or were redundant and were accurate, complete and easy to understand.

\subsubsection{Research Design}

There are many types of statistical analyses that can be employed to meet the objective of the research. The multiple regression is the most appropriate statistical analysis that can be used for this research as its objective is to examine the relationship and its interactions between board governance and school performance. In addition, all the variables (independent, dependent and control) are continuous for the independent variables that means board governance practices and their measurement was derived from the aggregated scores received by a school on each item identified as dimensions or variables.

By using multiple regressions, the study is able to understand how well the set of variables predicts a particular outcome. Multiple regressions enable to statistically control the impact of certain variables (control variables) when exploring the predictive ability of the model (Pallant, 2010). In the context of this research, multiple regressions enable to assist this study to determine and explore whether board governance is able to influence school performance. Control variables such as the size of the school, age and leverage can be regulated to limit the influence on the model predictability.

Generally, there are three types of multiple regressions that can be used in statistical analysis, namely standard multiple regression, stepwise multiple regression and hierarchical multiple regression. This study used standard multiple regression to analyze and explore the relationship between school performances (dependent variable) and board governance practices (independent variable) as well as the moderating variable used for the research.

This type of regression was chosen because it is a popular and well known statistical method used in the board governance empirical research. The dependent variable was regressed together with the independent and control variables. Each independent variable that is board governance sub index was evaluated in terms of its predictive power as compared to other independent and control variables. The impacts of control variables were analyzed as well. This method allows the amount of unique variance in the board performance of each of the board governance practices, school size, leverage and age explained. A similar approach had been used by many scholars in research related to board governance. (Like Krafft, Qu, Quatraro, and Ravix, 2013; Donker et al., 2008; Klapper and Love, 2004; Brown and Caylor, 2006).

\subsubsection{Experimental Manipulations or Interventions}

Quantitative analysis was performed on the data collected from the annual reports disclosed by the schools accessed for the research. These data were first posted to a Microsoft Excel Spreadsheet. Then, the data collected were manipulated, transformed and analyzed using SPSS.

\section{Results}

\subsection{Demografic Data Analysis}

In order to measure the demographical statistics, 06 questions were presented in the questionnaire. These questions cover the areas of gender, age, Educational qualification, Work experience, department in the board catergory and job level. These 06 questions were presented to the selected employees in the sample population. A summary of the weightage of each question in the questionnaire along with the percentage of the results are as mentioned below.

Table 1. Analysis of Gender

\begin{tabular}{lll}
\hline Gender & Number of board members & Percentage \\
\hline Female & 127 & $63.8 \%$ \\
Male & 72 & $36.2 \%$ \\
Total & 199 & $100 \%$ \\
\hline
\end{tabular}

As shown in table 1 . The percentage of females is $63.8 \%$ while the percentage of male is $36.2 \%$ out of the sample size of 199 board members.

Table 2. Age Analysis

\begin{tabular}{lll}
\hline Age & Number of board members & Percentage \\
\hline Less than 25 years & 30 & $15 \%$ \\
$26-40$ & 111 & $56 \%$ \\
$41-50$ & 33 & $17 \%$ \\
Above 50 & 25 & $12 \%$ \\
Total & 199 & $100 \%$ \\
\hline According & to &
\end{tabular}

According to table 2. Out of the 199 board members that was selected for the sample, $15 \%$ of the board members 
are less that 25 year of age and $17 \%$ are in between 41 to 50 years of age. The minority of the sample falls in the category of being 50 years and above with $12 \%$ of the sample size and the majority being between 26 to 40 years of age with populating $56 \%$ of the sample size.

Table 3. Educational Qualification Analysis

\begin{tabular}{lll}
\hline Educational level & Number of board members & Percentage \\
\hline GCE O/L & 72 & $36 \%$ \\
GCE A/L & 111 & $56 \%$ \\
Degree/Diploma or above & 16 & $8 \%$ \\
Total & 199 & $100 \%$ \\
\hline
\end{tabular}

As mentioned in table 3 the educational qualifications of the selected samples population are as follows. 8\% of the sample population is degree or diploma holders while $36 \%$ of the sample population has qualified with GCE $\mathrm{O} / \mathrm{L}$ results. The majority of the sample population according to table 3 is GCE A/L qualified board members.

Table 4. Analysis of Working Experience

\begin{tabular}{lll}
\hline Working Experience & Number of board members & Percentage \\
\hline Less than one year & 28 & $14 \%$ \\
one to five years & 41 & $20 \%$ \\
five to ten years & 65 & $33 \%$ \\
more than ten years & 65 & $33 \%$ \\
Total & 199 & $100 \%$ \\
\hline
\end{tabular}

According to table $4,14 \%$ of the employees in the selected sample has worked less than one year at boards and $20 \%$ of the members have worked in the organization for 1-5 years. $33 \%$ of members have worked between 5-10 years in the board association as well as $33 \%$ of members have worker over 10 years for school boards.

Table 5. Analysis of different boards

\begin{tabular}{lll}
\hline Boards & Number of employees & Percentage \\
\hline School Development Board & 64 & $32 \%$ \\
Past Pupil Association & 54 & $27 \%$ \\
Past teachers association & 36 & $18 \%$ \\
Wellfare board & 22 & $11 \%$ \\
Teaches Guide & 23 & $12 \%$ \\
Total & 199 & $100 \%$ \\
\hline
\end{tabular}

According to table 5 and figure 1, 32\% of board members are from the School Development Board while 27\% of members in the sample population are from the past pupil association. Also $18 \%$ of members belong to the past teachers association and $11 \%$ belongs to the Wellfare board while $12 \%$ belongs to the teachers guide.

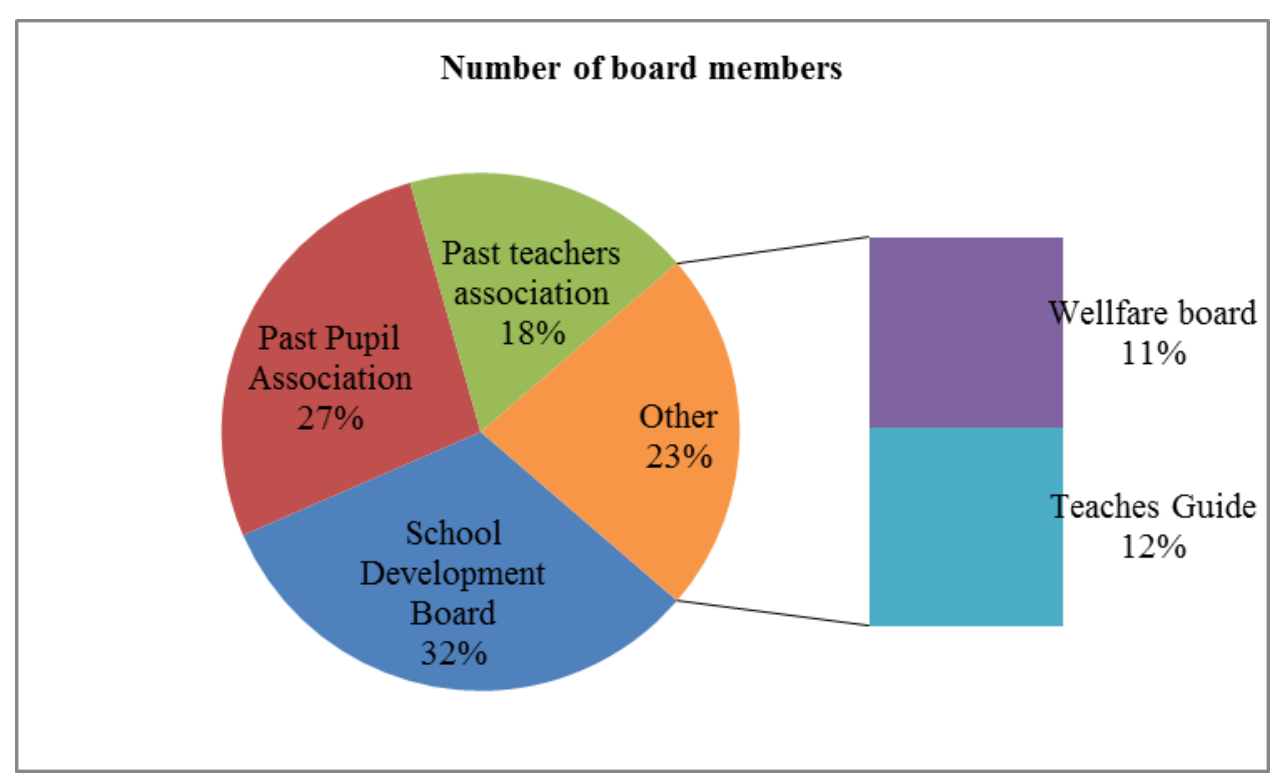

Figure 1. Analysis of different boards

\subsection{Statistics and Data Analysis}

Preliminary steps had been taken to ensure that only quality data were used before any statistical analysis was conducted. This will ensure that the correct findings will be produced (Sekaran \& Bougie, 2013). This process 
was started with the inspection of missing data and examining the data distributions of all the variables to confirm its normality and reliability.

\subsubsection{Missing Data}

Data screening to identify missing data or value was conducted to ensure that the data had been entered correctly. Data that were missing or wrongly entered will affect the results of the data analysis which will be carried out later. As this study was based on archival analysis, the problem of missing data can easily resolved. When the analysis of missing data was performed and the missing spot was recognized, the correct value was re-entered with the correct value or data. This was done by referring to the frequencies table for each item and variable. The correct value can be simply taken from the original score sheet of the company that had been analysed before and transferred into the statistical software used. This process was repeated until there was no missing data.

\subsubsection{Normality Test}

Normality tests were carried out to ensure that no extreme figures or outliers will distort the distribution of the data (Hair et al., 2006). Thus, data is considered normal when it has a symmetrical, bell shaped curve with the greatest frequencies of scores in the middle, with smaller frequencies towards either of the curve (Graveter \& Wallnu, 2004; Pallant, 2010). There are several ways on how normality test was conducted include Shapiro-Wilk test, followed by the Anderson-Darling test, Lilliefors test and Kolmogorov-Smirnov, skewness and kurtosis, histogram, quantile-quantile plot (QQ plot), box-plot and stem-and-leaf plot. All these non-normal distribution data of the relevant variables were transformed so that the distribution looked more normal. The transformations used were either square root or logarithm, depending on the skewness and kurtosis level of the relevant variables. This will allow the study to proceed to use the parametric analysis techniques after the normality assumption was met (Pallant, 2010; Tabachnik \& Fidell, 2013). Other than these variables, all the remaining variables were normally distributed and met the assumption of the parametric statistical analysis. In this analysis all variables are distributed in a normal distribution.

\subsubsection{Reliability Test}

Reliability test was important to avoid the study from having any random error. The reliability test employed in this study was internal consistency. The most common method to measure internal consistency is the Cronbach's alpha (Pallant, 2010; Smith, 2015). It indicates the average correlation among all the items in the scale. The value ranges from 0 to 1 . The higher the value, the higher the reliability of the scale (Pallant, 2010).

Table 6. Reliability Statistics

\begin{tabular}{lc}
\hline & Year-2016 \\
\hline \multirow{2}{*}{ Cronbach's Alpha } & Cronbach's Alpha Based on \\
0.929 & Standardized Items \\
\hline
\end{tabular}

Based on the results summarized in Table 6, the overall value of Cronbach's alpha for this study was 0.929 in 2013 and 0.932 in 2014, indicating a higher scale reliability. Nunnally and Bernstein (1994) and Sekaran and Bougie (2013) recommended the minimum reliability values of 0.7 and 0.8 respectively for the scale to be designated as reliable. A value of 0.7 is considered satisfactory (DeVellis, 2012), while value below than 0.6 is considered a poor reliability. A value of 0.8 is preferable for most research (Pallant, 2010)

\subsubsection{Assumptions of statistical analysis}

Before this analysis was carried out, several assumptions needed to be met to avoid false and inaccurate inferences (Hair et al., 2006; Tabachnick \& Fidell, 2013).

\subsubsection{Sample size}

Sufficient sample size is important to produce reliable statistical results (Field, 2009; Pallant, 2010). Small sample may lead to bias and wrong generalisation of the findings. The guide of the minimum sample can be based on the suggestions by Sekaran (2013), The final sample of this study was 199.

\subsection{Test of Correlations}

Correlation analysis is used to illustrate the strength and direction of the relationship between two variables (Pallant, 2010). The correlation values ranges from -1 (perfect negative correlation) to +1 (perfect positive correlation). Negative correlation is indicated as one variable increases, the other variable decreases, while positive correlation shows that both variables increase or decrease together. The nearer the value to 1 (either positive or negative), the higher the correlation between the variables. In contrast, the value that is near to 0 indicates a weak correlation or poor relationship between the variables. This study used the Pearson product-moment correlation coefficient (Pearson, symbol - r) as the variables in this study are continuous. It can 
also be used if the research had one continuous and one dichotomous variable.

Based on the correlations statistic, none of the independent variables had a correlation of more than 0.7. The highest value of correlation among the independent variables was board Charter with Web of 0.708 , significant at $1 \%$ significant level. However, in terms of correlation between the independent dependent variables, the majority of the values of the correlations were less than 0.3 , indicating a weak correlation value as suggested by Pallant (2010).

\subsection{Testing of Hypothesis}

- H1 Hypothesis was developed to identify the relationship between board clear function and school performance

H1o: There is no relationship between the existence of a board's clear function and school performance.

Hla: There is a relationship between the existence of a board's clear function and school performance.

Table 7. Correlations of Motivation and Descriptive Statistics

\begin{tabular}{llll}
\hline & & Board's clear funtion & School performance \\
\hline Board's clear funtion & Pearson Correlation & 1 & $\cdot$ \\
& Sig.(2-tailed) & &. \\
N & N & 199 & 1 \\
& Pearson Correlation & $.603^{* *}$ & 1 \\
& Sig.(2-tailed) & .000 & 199 \\
\hline
\end{tabular}

The Pearson's correlation value between Board's clear funtion and School performance is 0.603 at the significant level of 0.01 . Therefore it can be identified as a positive relationship among the two variables. According to this analysis, it can be concluded that H1a hypothesis, board clear funtion has a positive relationship with School performance. Therefor the null hypothesis H1o will be rejected. The standard deviation of the independent variable which is board clear funtion a value of 0.818 which means that the data collected from the questionnaire has been divided among the mean value of board clear funtion which is 3.312. The $\mathrm{R}$ square value shows that the relationship between board clear funtion $36 \%$ in variation with school performance.

- H2 Hypothesis was developed to identify the relationship between board sustainable policy and school performance

H2o: There is no relationship between the existence of a board's sustainable policy and school performance.

H2a: There is a relationship between the existence of a board's sustainable policy and school performance.

Table 8. Correlations of Motivation and Descriptive Statistics

\begin{tabular}{llll}
\hline & & Board's sustainable policy & School performance \\
\hline Board's sustainable policy & Pearson Correlation & 1 & \\
& Sig.(2-tailed) & & \\
& $\mathrm{N}$ & 199 & 1 \\
School performance & Pearson Correlation & $.627^{* *}$ & 199 \\
& Sig.(2-tailed) & .000 & 199 \\
& $\mathrm{~N}$ & 199 & \\
\hline
\end{tabular}

The Pearson's correlation value between Board sustainable policy and School performance is 0.627 at the significant level of 0.01 . Therefore it can be identified as a positive relationship among the two variables. According to this analysis, it can be concluded that H2a hypothesis, board clear funtion has a positive relationship with School performance. Therefor the null hypothesis $\mathrm{H} 2 \mathrm{o}$ will be rejected. The standard deviation of the independent variable which is board sustainable policy has a value of 0.681 which means that the data collected from the questionnaire has been divided among the mean value of sustainable policy which is 3.787. The R square value shows that the relationship between sustainable policy and school performance is $39 \%$ in variation with production efficiency

- H3 Hypothesis was developed to identify the relationship between board charter and school performance

H3o: There is no relationship between the board charter and school performance.

H3a: There is a relationship between the board charter and school performance. 
Table 9. Correlations of Motivation and Descriptive Statistics

\begin{tabular}{|c|c|c|c|}
\hline \multirow{2}{*}{ Board charter } & & Board charter & School performance \\
\hline & $\begin{array}{l}\text { Pearson Correlation } \\
\text { Sig.(2-tailed) }\end{array}$ & 1 & \\
\hline \multirow{3}{*}{ School performance } & $\mathrm{N}$ & 199 & \\
\hline & Pearson Correlation & $.708 * *$ & 1 \\
\hline & $\begin{array}{l}\text { Sig.(2-tailed) } \\
\mathrm{N}\end{array}$ & .000 & 199 \\
\hline
\end{tabular}

The Pearson's correlation value between Board chater and School performance is 0.627 at the significant level of 0.01 . Therefore it can be identified as a positive relationship among the two variables. According to this analysis, it can be concluded that H3a hypothesis, board clear funtion has a positive relationship with School performance. Therefor the null hypothesis $\mathrm{H} 3 \mathrm{o}$ will be rejected. The standard deviation of the independent variable which is board charter has a value of 0.481 which means that the data collected from the questionnaire has been divided among the mean value of sustainable policy which is 3.907. The $\mathrm{R}$ square value shows that the relationship between sustainable policy and school performance is 50\% in variation with production efficiency.

\subsection{Summary of the Correlations}

Table 10. mmary of the Correlations

\begin{tabular}{llll}
\hline Variables & Pearson's correlation & Significance & R Square Value \\
\hline Board clear funtion & 0.603 & 0.01 & 0.364 \\
Sustainable policy & 0.627 & 0.01 & 0.393 \\
Board charter & 0.708 & 0.01 & 0.501 \\
\hline
\end{tabular}

According to the analysis of the data, three positive relationships have been identified between bosrd clear function, sustainable policy and board charter with school performance. When considering the R square values, it can be understood that the variations among the independent variables has had an impact on the dependent variable. Therefor with the analysis of data gathered from the questionnaire and through the literature review, it can be concluded that motivation, line balancing and scientific workstation layout has a positive relationship with the school performance.

\section{Discussion}

From the data that was analysed through hypotheses testing, the relationship between the dependent and independent variables were identified. The analysis of data for independent variable board clear funtion and dependent variable school performance indicates that it has a correlation of 0.603 and the $\mathrm{R}$ square value of 0.364 with a 0.01 level of significance. This analysis reveals the positive relationship between board clear funtion and school performance. Therefor H1a hypothesis is accepted whereas H1o hypothesis is rejected.

From the data that was gathered from the questionnaires and the literature reviews it is evident that board clear funtion plays a vital part in the performance of schools. It also allows the school to control and minimize factors such effect into performance of the scool. After the analysis of data in relation of board sustainable policy and school performance, the correlation was indicated as 0.627 as well as the R square value as 0.393 with a 0.01 level of significance. This indicates that the relationship between the independent variable sustainable policy and dependent variable school performance is positive, which means when line balancing increases the production efficiency would increase. Therefor H2a hypothesis is accepted while H2o Hypothesis is rejected. The analysis of data from the questionnaire for independent variable board charter and dependent variable school performance, the correlation is indicated as 0.708 while the $\mathrm{R}$ square value is identified as 0.501 with a level of 0.01 significance. This indicates a strong positive relationship between board charter and school performance, which can be understood as when the accuracy of implementing the board charter in the boards increases the school performance. Therefor $\mathrm{H} 3 \mathrm{a}$ hypothesis can be accepted while $\mathrm{H} 3 \mathrm{o}$ hypothesis will be rejected. In conclusion, the research problem was analysed through the established research objectives. To initially analyse the validity of the research objectives, a literature review was developed through past research and studies that was conducted in the same area relating to school performance. A conceptual framework was then developed to further clarify the objectives in to independent and dependent variables and the established relationship among them. The dependent variable was then declared as school performance and the independent variables were declared as board clear funtion, sustainable policy and board charter.

\section{References}

Adams, C. A. (2002). Internal organisational factors influencing corporate social and ethical reporting: Beyond current theorising. Accounting, Auditing \& Accountability Journal, 15(2), 223-250. https://doi.org/10.1108/09513570210418905 
Adams, C., \& Zutshi, A. (2004). Corporate social responsibility: why business should act responsibly and be accountable. Australian Accounting Review, 14(34), 31-39. https://doi.org/10.1111/j.1835-2561.2004.tb00238.x

Adams, R. B., \& Ferreira, D. (2007). A theory of friendly boards. The Journal of Finance, 62(1), 217-250. https://doi.org/10.1111/j.1540-6261.2007.01206.x

Armstrong, C. S., Guay, W. R., \& Weber, J. P. (2010). The role of information and financial reporting in corporate governance and debt contracting. Journal of Accounting and Economics, 50(2-3), 179-234. https://doi.org/10.1016/j.jacceco.2010.10.001

Armstrong, K. (2010). The case for God. Random House Digital, Inc..

Ashwin, A. S., Krishnan, R. T., \& George, R. (2016). Board Characteristics, Financial Slack and R\&D Investments: An Empirical Analysis of the Indian Pharmaceutical Industry. International Studies of Management \& Organization, 46(1), 8-23. https://doi.org/10.1080/00208825.2015.1007007

Bebchuk, L. A., \& Weisbach, M. S. (2010). The state of corporate governance research. The Review of Financial Studies, 23(3), 939-961. https://doi.org/10.1093/rfs/hhp121

Bhagat, S., \& Bolton, B. (2008). Corporate governance and firm performance. Journal of corporate finance, 14(3), 257-273. https://doi.org/10.1016/j.jcorpfin.2008.03.006

Blair, J. A. (2012). The rhetoric of visual arguments. In Groundwork in the Theory of Argumentation (pp. 261-279). Springer, Dordrecht. https://doi.org/10.1007/978-94-007-2363-4_19

Boeker, W., \& Goodstein, J. (1991). Organizational performance and adaptation: Effects of environment and performance on changes in board composition. Academy of Management Journal, 34(4), 805-826.

Brown, L. D., \& Caylor, M. L. (2006). Corporate governance and firm valuation. Journal of accounting and public policy, 25(4), 409-434. https://doi.org/10.1016/j.jaccpubpol.2006.05.005

Bushman, R. L. (2004). Believing History: Latter-day Saint Essays. Columbia University Press.

Cadbury, A. (1992). Report of the committee on the financial aspects of corporate governance (Vol. 1). Gee.

Carpenter, M. A., \& Westphal, J. D. (2001). The strategic context of external network ties: Examining the impact of director appointments on board involvement in strategic decision making. Academy of Management journal, 44(4), 639-660.

Cassar, G., Ittner, C. D., \& Cavalluzzo, K. S. (2015). Alternative information sources and information asymmetry reduction: Evidence from small business debt. Journal of Accounting and Economics, 59(2-3), 242-263. https://doi.org/10.1016/j.jacceco.2014.08.003

Cheng, B., Ioannou, I., \& Serafeim, G. (2014). Corporate social responsibility and access to finance. Strategic Management Journal, 35(1), 1-23. https://doi.org/10.1002/smj.2131

DeVellis, R. F. (2012). Validity. Scale development: Theory and applications, 3.

Donaldson, L., \& Davis, J. H. (1994). Boards and company performance - research challenges the conventional wisdom. Corporate governance: An international review, 2(3), 151-160. https://doi.org/10.1111/j.1467-8683.1994.tb00071.x

Fama, E. F., \& Jensen, M. C. (1983). Separation of ownership and control. The journal of law and Economics, 26(2), 301-325. https://doi.org/10.1086/467037

Field, A. (2009). Discovering statistics using SPSS. Sage publications.

Gravetter, F. J., \& Wallnau, L. B. (2004). Statistics for the behavioral sciences: A short course and student manual.

Hair Jr, J. F. (2006). Black, WC, Babin, BJ Anderson, RE \& Tatham, RL (2006). Multivariate data analysis, 6.

Hillman, A. J., \& Dalziel, T. (2003). Boards of directors and firm performance: Integrating agency and resource dependence perspectives. Academy of Management review, 28(3), 383-396. https://doi.org/10.5465/amr.2003.10196729

Inderst, R., \& Mueller, H. M. (2010). CEO replacement under private information. The Review of Financial Studies, 23(8), 2935-2969. https://doi.org/10.1093/rfs/hhq018

Jensen, M. C., \& Meckling, W. H. (1976). Theory of the firm: Managerial behavior, agency costs and ownership structure. Journal of financial economics, 3(4), 305-360. https://doi.org/10.1016/0304-405X(76)90026-X 
Keay, A., \& Loughrey, J. (2015). The framework for board accountability in corporate governance. Legal Studies, 35(2), 252-279. https://doi.org/10.1111/lest.12058

Klapper, L. F., \& Love, I. (2004). Corporate governance, investor protection, and performance in emerging markets. Journal of corporate Finance, 10(5), 703-728. https://doi.org/10.1016/S0929-1199(03)00046-4

Neuman, S. B. (2006). The knowledge gap: Implications for early education. Handbook of early literacy research, 2, 29-40.

Nicholson, G. J., \& Kiel, G. C. (2007). Can directors impact performance? A case - based test of three theories of corporate governance. Corporate Governance: An International Review, 15(4), 585-608. https://doi.org/10.1111/j.1467-8683.2007.00590.x

Nobanee, H., \& Ellili, N. (2016). Corporate sustainability disclosure in annual reports: Evidence from UAE banks: Islamic versus conventional. Renewable and Sustainable Energy Reviews, 55, 1336-1341. https://doi.org/10.1016/j.rser.2015.07.084

Orlitzky, M., Schmidt, F. L., \& Rynes, S. L. (2003). Corporate social and financial performance: A meta-analysis. Organization studies, 24(3), 403-441. https://doi.org/10.1177/0170840603024003910

Orsato, R. J. (2006). Competitive environmental strategies: when does it pay to be green? California management review, 48(2), 127-143. https://doi.org/10.2307/41166341

Pallant, J. (2010). SPSS survival manual: A step by step guide to data analysis using SPSS . Maidenhead.

Raheja, C. G. (2005). Determinants of board size and composition: A theory of corporate boards. Journal of financial and quantitative analysis, 40(2), 283-306. https://doi.org/10.1017/S0022109000002313

Ravina, E., \& Sapienza, P. (2010). What do independent directors know? Evidence from.

Sekaran, U., \& Bougie, R. (2013). Edisi 6. Research Methods For Business.

Škare, M., \& Hasić, T. (2016). Corporate governance, firm performance, and economic growth-theoretical analysis. Journal of Business Economics and Management, 17(1), 35-51. https://doi.org/10.3846/16111699.2015.1071278

Smith, J. A. ed., (2015). Qualitative psychology: A practical guide to research methods. Sage.

van den Donker, M. J. (2008). Modelling microwave plasmas for deposition purposes: exploring the freedom in space and chemistry.

\section{Copyrights}

Copyright for this article is retained by the author(s), with first publication rights granted to the journal.

This is an open-access article distributed under the terms and conditions of the Creative Commons Attribution license (http://creativecommons.org/licenses/by/4.0/). 